\title{
O impacto da Autoria em Rede e das Produções Colaborativas no processo de aprendizagem para além da transmidiação
}

\section{The impact of Networked Authorship and Collaborative Productions on the learning process beyond transmedia}

DOI: $10.46814 /$ lajdv3n4-051

Recebimento dos originais: 01/05/2021

Aceitação para publicação: 31/06/2021

\section{Cecília Mello de Oliveira}

Jornalista graduada pela Universidade Tiradentes; Endereço: Rua Soldado Oscar Vinhas, Número

214, Conjunto Orlando Dantas, Bairro São Conrado, Aracaju - Sergipe

E-mail: ceciliamoliveira4@gmail.com

\section{Renata Tavares Benia}

Doutoranda em Dimensão estética e semiótica das imagens e Membro da rede de pesquisa em teoria da fotografia

E-mail: renatabenia@gmail.com

\section{Cristiane Porto}

Doutora Multidisciplinar em Cultura e Sociedade - UFBA, Membro do Programa de Pós-Graduação em Políticas Públicas, Estratégia e Desenvolvimento da Universidade Tiradentes e diretora da Editora da Universidade Tiradentes

E-mail: crismporto@gmail.com

\section{RESUMO}

O presente projeto tem como finalidade propor uma aproximação teórica e prática a respeito da autoria em rede e das produções colaborativas no espaço on-line enquanto fatores promissores no processo de aprendizagem despertado por um teor transmidiático. Consideram-se como aporte teórico discussões acerca da autoria em rede, da atividade colaborativa, do cenário da cibercultura, bem como convergência midiática e narrativa transmidiática. Para tanto, parte-se do método qualitativo, a partir da leitura bibliográfica e finalidade exploratória e descritiva para destacar a discussão e possíveis resultados por meio dos dados analisados. Buscando assim, observar a relevância e caminhos possíveis na educação a partir de tais exercícios.

Palavras-chaves: Transmídia, Fanfiction, Educação.

\begin{abstract}
The purpose of this project is to propose a theoretical and practical approach regarding networked authorship and collaborative productions in the online space as promising factors in the learning process triggered by a transmedia content. We consider as theoretical basis discussions about networked authorship, collaborative activity, the cyberculture scenario, as well as media convergence and transmedia narrative. For this, the qualitative method is used, based on bibliographical reading and exploratory and descriptive purposes to highlight the discussion and possible results through the analyzed data. Thus, we seek to observe the relevance and possible paths in education from such exercises.
\end{abstract}

Keywords: Transmedia, Fanfiction, Education. 


\section{INTRODUÇÃO}

O tema proposto tem como utilizar o espaço on- line no cenário da educação, abordando a narrativa transmídia e como ela pode oferecer novos meios de estudo. A fanfiction, por exemplo, é o principal foco de observação e sua importância noaprendizado.

O conteúdo de um filme, livro ou série, leva aos fãs usarem a escrita e o conhecimento para produzirem algo novo a partir daquele produto, incentivando a leitura e a escrita. Franquias de sucesso acabam gerando impacto na cultura de massa, formandouma comunidade de conhecimento.

O avanço tecnológico e a facilidade de gerar e receber informações, trás um novo tipo de cultura e comportamento. A educação também evolui e novosmeios de aprendizagem surgiram como a produção colaborativa que pode ser feita por meio de vídeos, textos e fotos complementando o estudo.

Em a Cultura da Convergência (JENKINS, 2009)explica o modo e a influencia que os fãs tiveram - e ainda tem nos tempos atuais na indústria midiática. O efeito de um programa de TV causa em seu público uma mudança no comportamento de seu receptor. O interesse do público, a cultura de massatornou-se cada vez maior e significativa nos tempos atuais.

A comunidade de fãs cresceu e a rotina diária de cada um baseia-se no horário de exibição do seu show preferido. A inteligência coletiva transformou aforma da cultura de massa.

A inteligência coletiva irá, gradualmente, alterar o modo como a cultura de massa opera. Ele considera míope o pânico da indústria com a participação do público (LÉVY, 2009, p. 55).

Isso quer dizer que a cultura do conhecimento, os laços sociais de forma antiga estão diminuindo com o avanço tecnológico e novas formas de se comunicar estão surgindo com as novas mídias de interação social e educacional.

O processo de criação é muito mais divertido e significativo se você puder compartilhar sua criação com outros, e a web, desenvolvida para fins de cooperação dentro da comunidade científica, fornece uma infraestrutura para o compartilhamento.(JENKINS, 2009, p. 201)

Quando a junção da criatividade e o conhecimento,o emissor passa a entender o significado da mensagem, assim os assuntos tratados passam a ter um interesse maior. (Para aquele que emiti e recebe o conteúdo).

Os fóruns criados para a discursão sobre um determinado tema é um exemplo de como acontece o compartilhamento. Nele a exposição de ideias, opiniões, assuntos desenvolvem argumentos que constroem novas percepções sobre aquele tema. 


\subsection{OS FÓRUNS TROUXERAM UM NOVO CONTEXTO PARA A EDUCAÇÃO.}

A literatura é a principal matéria envolvida nesse novo artifício de ensino. A leitura e a escrita são incentivadas e a arte é resgatada a um novo parâmetro na visão do aprender. A produção denovas mídias voltada a essa temática passam conceitos e tópicos.

O impacto com o surgimento da Cultura da Convergência trouxe um novo pensamento de como a informação é emitida e recepcionada. A sociedadeconectada torna-se cada vez mais próxima e com o maior acesso a conteúdos, elevando o intelectual eo grau conhecimento gerais e específicos.

\section{REVISÃO DE LITERATURA}

A pesquisa bibliográfica feita tem como aprofundar sobre o tema proposto.

A obra como base escolhida foi a Cultura da Convergência. Nela apresenta um novo tipo de cultura e marco sobre a atividade colaborativa, do cenário da cibercultura, bem como convergência midiática e narrativa transmidiática.

A relação das mídias com a atual realidade assume um interesse no receptor pela busca de informações. E como o mundo cibernético evolui na educação.

Tendo foco à exploração de atividades em rede da criação, mas que tenham um teor transmidiático, na medida em que se observam quais ferramentas são decisivas para criação deste conteúdo.

A interatividade proporciona novas mudanças e conceitos na sociedade, transformando um produto em várias mídias.

\section{RESULTADOS E DISCUSSÃO}

Preferencias e o direcionamento para qualquer conteúdo.

A educação não seria diferente à medida que a narrativa transmídiatica é introduzida no ambientede ensino, novos caminhos são estabelecidos e o interesse no aprendizado cresce.

\section{CONCLUSÕES}

A internet é uma ferramenta poderosa, ela renovou a cultura e programou novos meios comportamentais.

O uso da transmídia na educação irá incentivar nas produções textuais, intepretações e a criatividade. Além de desenvolver uma leitura critica. 


\section{REFERÊNCIAS}

JENKINS, Henry. Cultura da Convergência. 2. ed. São Paulo: Aleph, 2009. 428 pp. ISBN 978-857657-084-4 (trad. Susana Alexandria)

Segundo Jenkins (2009, p170), "Histórias são fundamentais em todas as culturas humanas, o principal meio pelo qual estruturamos, compartilhamos e compreendemos nossasexperiências comuns".

É fundamental em uma sociedade conectada, pesquisar e se informar sobre cada assunto, novidade e notícia, pois são elas que movem o mundo e aproximam todos os indivíduos.

O interesse em comum é essencial para qualquer grupo, são eles que determinam as 